Innlegg på inntil 400 ord lastes opp i http://mc.manuscriptcentral.com/tidsskriftet.

Redaksjonen forbeholder seg retten til å foreta redaksjonelle endringer.

Forfattere av vitenskapelige artikler har automatisk tilsvarsrett (jf. Vancouver-gruppens regler).

\section{Feilaktig om forandringer i cervikalcolumna}

Vi leste med interesse Per Holcks redegjørelse for cervikalcolumnas anatomi i Tidsskriftet nr. 1/2010 (1) og ble derfor overrasket over at avsnittet om skader i cervikalcolumna var så lite basert på oppdatert kunnskap om forekomsten av degenerative forandringer i normalpopulasjonen. Holck hevder at lokale forandringer i ett eller to nivåer i nakken («skivereduksjoner, kalkpåleiringer etc.») oftest er en følge av eldre skader, selv om pasienten ikke husker dette selv.

Denne fremstillingen av sammenhengen mellom degenerative forandringer (spondylose) og tidligere skader mangler helt vitenskapelig dokumentasjon og kan føre til feilaktige slutninger om årsakssammenheng. Vi forutsetter at det Holck kaller «skivereduksjoner» og «kalkpåleiringer» er det som i litteraturen omtales som «cervical spondylosis» eller «degeneration of the spine». Det er i løpet av de siste ti år publisert en rekke studier som viser at denne type degenerative forandringer forekommer meget hyppig i normalbefolkningen. Tradisjonelt har man knyttet slike forandringer i rygg og nakke til mekanisk belastning. Et begrep som «slitasjeforandringer» bygger opp rundt oppfatningen av at den mekaniske belastningen er viktig. Tvillingstudier har imidlertid vist at så mye som $50-70 \%$ av forskjellene i grad av degenerasjon mellom ulike individer kan tilskrives genetiske faktorer (2). Signalintensitet i skivene på MR er klart korrelert til alder, og $90 \%$ av asymptomatiske 60 -åringer vil ha slike signalforandringer i skivene $(3,4)$. Det er ikke vist noen sikker og klinisk viktig sammenheng mellom forekomsten av slike degenerative skiveforandringer og pasientens symptomer i verken nakke eller rygg $(5,6)$. En japansk oppfølgingsstudie har vist at det er progregrediering av degenerative forandringer i nakken hos $80 \%$ av symptomfrie forsøkspersoner over ti år (redusert skivehøyde hos $27 \%$ ). Den eneste risikofaktor for utvikling av denne type forandringer som ble identifisert, var alder (7). Disse degenerative forandringene må altså oppfattes som en del av normal aldring.

Etter vår mening finnes det $\mathrm{i}$ dag ingen dokumentasjon på at denne type vanlig forekommende degenerative forandringer i nakken skyldes tidligere skade, og vi vil på det sterkeste fraråde at skade benyttes som etiologisk forklaring for den enkelte pasient.

\section{$\emptyset y s t e i n$ P. Nygaard \\ Tomm B. Müller \\ Magne Rø \\ Kjell Arne Kvistad \\ Gunnar Leivseth \\ Trondheim}

\section{Litteratur}

1. Holck P. Cervikalkolumnas anatomi. Tidsskr Nor Legeforen 2010; 130: 29-32.

2. Adams MA, Roughly PJ. What is intervertebral disc degeneration and what causes it? Spine 2006; 31 . 2151-61.

3. Malfair D, Baell DP. Imaging the degenerative diseases of the lumbar spine. Magn Reson Imaging Clin N Am 2007; 15: 221-38.

4. Shedid D, Benzel EC. Cervical spondylosis anatomy: pathophysiology and biomechanics. Neurosurgery 2007; 60 (suppl 1): 7-13.

5. Modic MT, Ross JS. Lumbar degenerative disk disease. Radiology 2007; 245: 43-61.

6. Abbed KM, Coumans JVCE. Cervical radiculopathy: pathophysiology, presentation, and clinical evaluation. Neurosurgery 2007; 60 (suppl 1): 28-34.

7. Okada E, Matsumoto M, Ischihara D et al. Aging of the cervical spine in healthy volounteers. Spine 2007; 34: 706-12

\section{P. Holck svarer:}

Jeg kan ikke se at de innvendinger som kollegene Nygaard, Müller, Rø, Kvistad og Leivseth har mot min oversiktsartikkel, er innvendinger i det hele tatt. Jeg er faktisk enig i det meste av det de skriver - jeg er redd de har oppfattet meg altfor bokstavelig. Med begrenset spalteplass til disposisjon

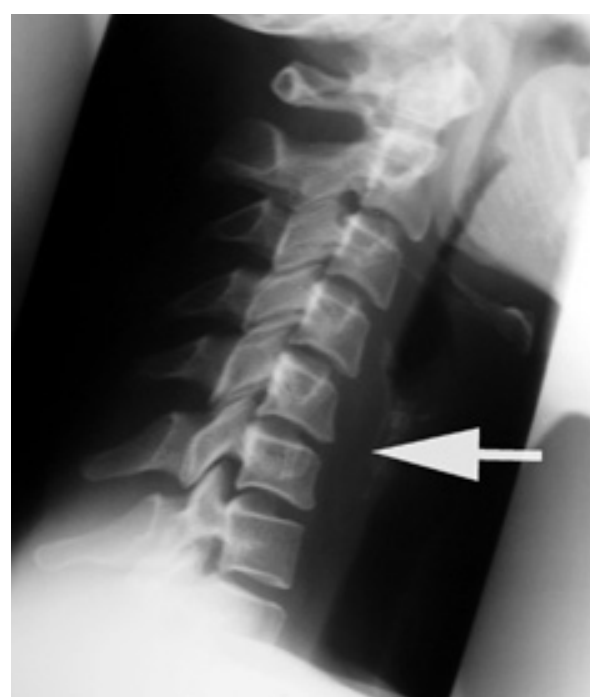

Figur 1 «Normalt» resultat, selv om pasienten har nakkesmerter. Bildet er tatt ca. fire måneder etter skaden blir ofte artiklenes innhold for kort til at man kan få med alt man ønsker å uttrykke.

Når jeg skriver «eldre skader», mener jeg ikke nødvendigvis større saker som bilkollisjoner etc. Det ville pasienten sikkert ha husket. Jeg tenker mer på de små, hverdagslige uhellene som de fleste av oss opplever gjennom hele livet og som vi lett glemmer: Det lille rundkastet på glattisen, den stive nakken man fikk etter en dårlig natts søvn, taklingen under fotballturneringen etc. Er det ikke nettopp derfor at de «forekommer meget hyppig i normalbefolkningen», at de er «klart korrelert til alder» og at $« 90 \%$ av asymptomatiske 60 -åringer vil ha slike signalforandringer i skivene», slik innsenderne skriver?

At selv en dokumentert, eldre skade kan være uten symptomer, skulle være velkjent. At de degenerative forandringene progredierer likeså. $\mathrm{Og}$ - ja visst - det går svært langsomt, for osteogenesen er en sendrektig prosess, og ofte synes ikke nydanningene forårsaket av en periostal reaksjon - før etter 5-10 år. Jeg vedlegger eksempelvis to bilder av en pasient, tatt med sju års mellomrom. Vedkommende hadde nakkesmerter, men benektet traume, inntil et fall noen måneder tidligere ble nevnt. Det første bildet (fig 1) ble beskrevet som «normalt», tross kyfotisk knekk og antydet skivereduksjon C5-6 (pil). Det andre bildet (fig 2) viser resultatet av denne «ubetydelighet», den gang med atskillige plager, i dag med tilnærmet symptomfrihet - dog med langt-

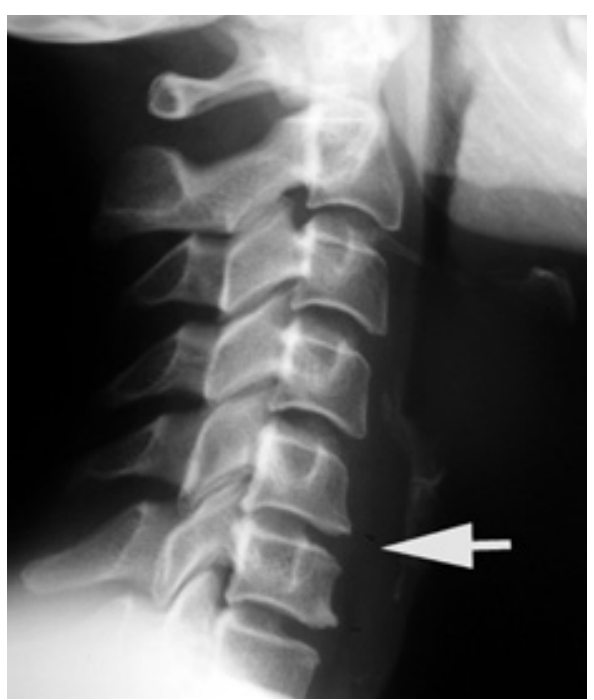

Figur 2 Sju år senere volder skaden pasienten atskillige plager 